\title{
Pharmacological evaluation of Rumex vesicarius Linn leaf extract and fractions in rabbit gastrointestinal ailment
}

\author{
Imran Ahmad Khan ${ }^{1 \star}$, Abdul Aziz ${ }^{1}$, Fatima Saqib ${ }^{1}$, Shaukat Hussain Munawar ${ }^{2}$, \\ Zahid Manzoor ${ }^{2}$ and Muhammad Asif Raza ${ }^{3}$ \\ ${ }^{1}$ Faculty of Pharmacy, Bahauddin Zakariya University, Multan, Pakistan. \\ ${ }^{2}$ Faculty of Medicine and Allied Medical Sciences, Isra University, Islamabad, Pakistan. \\ ${ }^{3}$ Animal Husbandry in Tropics and Subtropics, University of Kassel, Germany.
}

Received 13 February, 2014; Accepted 25 March, 2014

\begin{abstract}
The aqueous-methanolic leaf extract and fractions of the Rumex vesicarius L. (Rv.Cr) was evaluated for the possible presence of spasmogenic and spasmolytic constituents to rationalize its traditional uses in gastrointestinal disorders. In rabbit jejunum, $R$. vesicarius caused a dose-dependent $(0.03$ to $0.3 \mathrm{mg} / \mathrm{ml})$ weak stimulatory effect on spontaneous contractions, followed by relaxation at the next higher dose ( 1 $\mathrm{mg} / \mathrm{ml})$. In the presence of atropine $(0.03 \mu \mathrm{M})$, the spasmogenic effect was abolished and the relaxant effect was obtained at lower doses $(0.1$ to $1.0 \mathrm{mg} / \mathrm{ml})$ shifting the dose response curves to the left. The spasmolytic effect on the spontaneous and $\mathrm{K}^{+}$-induced contractions in atropinized preparations was mediated at doses 0.03 to $1.0 \mathrm{mg} / \mathrm{ml}$ and 0.3 to $5 \mathrm{mg} / \mathrm{ml}$, respectively which explained the involvement of calcium channel blocking (CCB) effect. The CCB effect was confirmed when pretreatment of the tissue with $R$. vesicarius produced a dose-dependent shift in the $\mathrm{Ca}^{++}$dose-response curves to the right in a similar manner as verapamil. Activity-directed fractionations revealed that the spasmolytic effect was concentrated in methanolic fraction, while spasmogenic activity in the aqueous fraction which was remarkably stronger than aqueous-methanolic extract. This data shows that the crude leaf extract of $R$. vesicarius $L$. contains spasmogenic and spasmolytic constituents mediating their effect through cholinergic and CCB actions, respectively, which explains its traditional use in the gastrointestinal disorders such as abdominal colics and cramps, constipation and diarrhea, gestroesophagial reflux disease and irritable bowel syndrome/inflammatory bowel disease.
\end{abstract}

Key words: Rumex vesicarius Linn, spasmogenic, Spasmolytic, Cholinergic, CCB.

\section{INTRODUCTION}

Constipation and diarrhea, colic and cramps are affecting $70 \%$ of the population worldwide (Quyang and Chin, 2004). Developing countries such as Pakistan, India and Bangladesh are commonly facing gastrointestinal disorders due to low standard sanitary conditions. Acute diarrhea is usually caused by an infectious agent, even though drugs, poisons or acute inflammatory reactions can contribute a lot (Thapar and Sanderson, 2004). Rotavirus is the major causative agent for infectious diarrhea, especially in young ones. However, other

*Corresponding author: E-mail: imranahmadkhadurrani@gmail.com. Tel: 923143005013. 
microbial agents viral (adenovirus, enterovirus and norovirus), bacterial (Shigella species, Escherichia coli, Salmonella species, Camphylobacter and Vibrio cholerae) and parasitic (Cryptosporidium and Giardia) also disturbs the normal tone of gastrointestinal tract (Allen et al., 2004). Rumex vesicarius Linn., locally known as "Khat palak". $R$. vesicarius $\mathrm{L}$. has been used traditionally for ally pain of toothache, as astringent for nausea, cooling agent, anti-venom, and insect bite, and as appetizer, seeds were used for dysentery (Dymoke, 1972). In Ayurvedic system of medication, it was used as stomachic (Ahirrao et al., 2012), analgesic, anti tumor, laxative, flatulence, spleen disease, high cough, asthma, bronchitis, dyspepsia, heart troubles, alcoholism, and biliousness (Kirtikar and Basu, 1987). In Unani system of medication, it was used as analgesic, tonic, leucoderma, for scabies, and diuretic (Kirtikar and Basu, 1987). In other folk medicines, it was used to eradicate, hiccup, piles, and constipation (Hariparasad, 2011). Reptile insect, hepatoprotective, depurative, dysmenorrhoea, blood purifier, sedative, alkalinity, dyspepsia, urinary affection, chronic catarrh, renal disorders, bloody dysentery, and coronary (Madhavashetty et al., 2008), vomiting (Khan et al., 2013), antiviral, antidiabetic, leucoderma, lymphatic glyndular system disease, rectal prolapsus, aphrodisiac anti-cholesterol, impetigo, and carbubuncles (Nardkarnis, 2008; Pullaiah and Ali, 1999), antioxidant (Rao, 2003), stomach ache (Rao and Patil, 2012), diuretic (Rao et al., 2011), cancer and inflammation (Aggarwal et al., 2006), anti-fungal (Amira et al., 2011), anthelmintics (Rao et al., 2012), and antipyretic (Khan et al., 2013).

This study reports the spasmodic and antispasmodic activity of aqueous methanolic leaf extract of $R$. vesicarius Linn and its fractions.

\section{MATERIALS AND METHODS}

Plant

Indigenous medicinal plant $R$. vesicarius $\mathrm{L}$. known by a local name of "Khat palak" belongs to family Polygonaceae. The plant was collected from the sandy fields of Mondka Shahlamal District, Muzaffar Garh, Pakistan. The plant material was authenticated by expert taxonomist, Professor Dr. A. H. Dasti at the Department of Botany, Bahauddin Zakariya University, Multan, Pakistan (voucher F.P.ST-215). The plant material was made free from foreign adulterants and vegetative debris by hand picking and leaves were detached from the plant, washed and shade dried. Within 8 days, leaves became crispy. Special electrical herbal grinder was used to form coarse powder. Uniform dark green powder was obtained with characteristic smell.

\section{Crude extract}

The powdered plant material $(1 \mathrm{~kg})$ was subjected to maceration in $70 \%$ methanol in amber coloured glass bottle at room temperature for 8 days with occasional shaking (Harborne, 1973). The soaked material was passed through muslin cloth to remove the vegetative material and the fluid obtained was filtered through Whattman-1 Filter paper. The filtrate was evaporated on a rotary evaporator (Rotavapor, BUCHI labrotechnik AG, Model 9230, Switzerland) at $37^{\circ} \mathrm{C}$ under reduced pressure. Approximate yield was $11 \%$ and the extract obtained was stored at $-4^{\circ} \mathrm{C}$ in air tight jars in lab refrigerator.

\section{Preliminary phytochemical screening}

Phytochemical screening was done for the presences of vital phytochemical classes by the method described by Tona et al. (1998).

\section{Chemicals and drugs}

All the chemicals, solvents, and drugs used were of analytical grade. Acetylcholine chloride and atropine sulfate were purchased from Ethical Laboratories Pvt. (Ltd) Pakistan. Dimethylsulfoxide, ethylenediamine tetraacetic acid, glucose, magnesium chloride, magnesium sulfate, potassium chloride, potassium dihydrogenophosphate, sodium chloride, sodium bicarbonate, and sodium dihydrogenophosphate were purchased from Sigma Chemical Company, St. Louis, MO, USA. Calcium chloride was purchased from Merck (Merck, Darmstadt, Germany).

\section{Animals and housing condition}

Ten adult albino rabbits ( 1.0 to $1.5 \mathrm{~kg}$ ) of either sex, purchased from the local market with age limit between 6 and 7 months were used for the experiments. Animals were provided with fresh green fodder and tap water ad libitum and maintained in air conditioned room (23 to $25^{\circ} \mathrm{C}$ ) at the Faculty of Pharmacy, Bahauddin Zakariya University, Multan. All rabbits were kept in fasting condition for at least $24 \mathrm{~h}$ before the commencement of experiments, but had free access to water. The experiments were approved by the Ethical Committee of the Bahauddin Zakariya University, Multan, with reference number EC/12/2012 dated 07 December 2012.

\section{Plant extract solution}

The plant extract $(0.3 \mathrm{~g})$ was dissolved in $1 \mathrm{ml}$ of methanol to produce stock solution. From this stock solution further dilutions were made. Solutions were freshly prepared on the day of experiment.

\section{Antispasmodic activity}

We used the procedure described by Farre et al. (1991) to screen spasmolytic activity. Contractions in the intestine portions were produced by high $\mathrm{KCl}(80 \mathrm{mM})$ to depolarize the intestine portions (Farre et al., 1991). The extracts were then applied in similar fashion to relax the tissues and percentage relaxation response on $\mathrm{KCl}$ induced contractions was recorded as shown in Figure 1. The following formula was used for calculations:

Inhibition/Stimulation $(\%)=100-\frac{\text { Average height of normal contraction }(\mathrm{mm})}{\text { Average height of contractions after extract }(\mathrm{mm})} \times 100$

\section{Spasmodic activity}

The extract was screened for possible cholinomimetic activity as per procedure mentioned. Tyrode's solution was prepared having 
Control

a
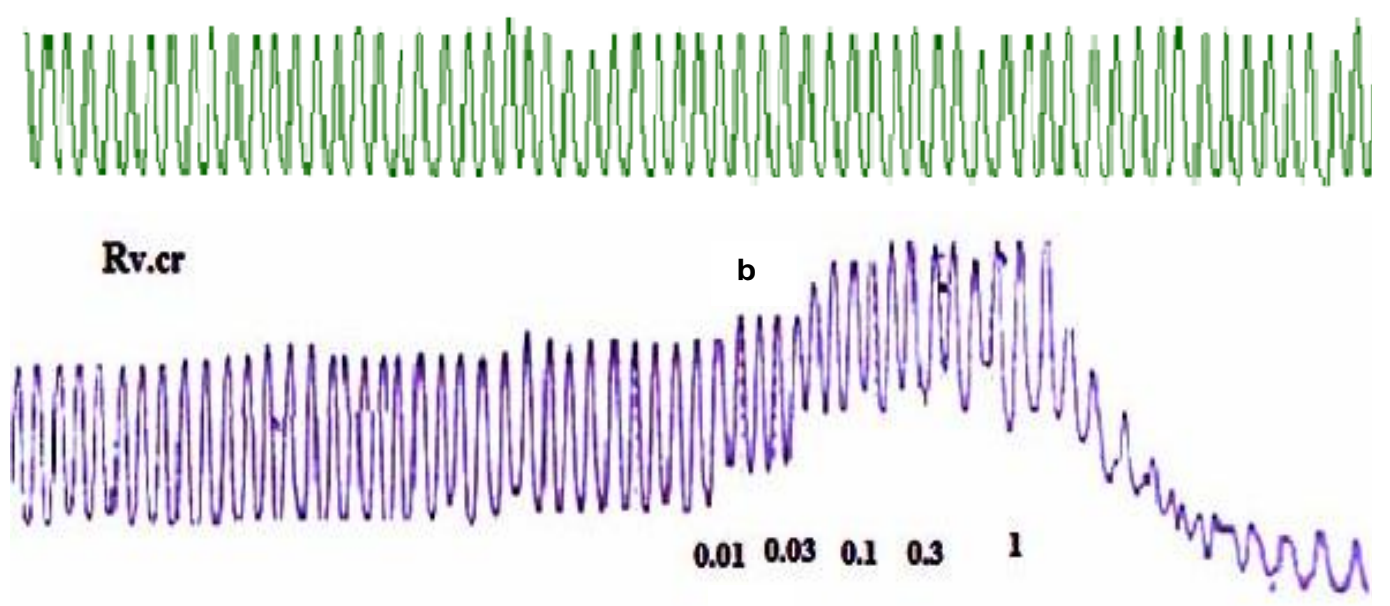

c

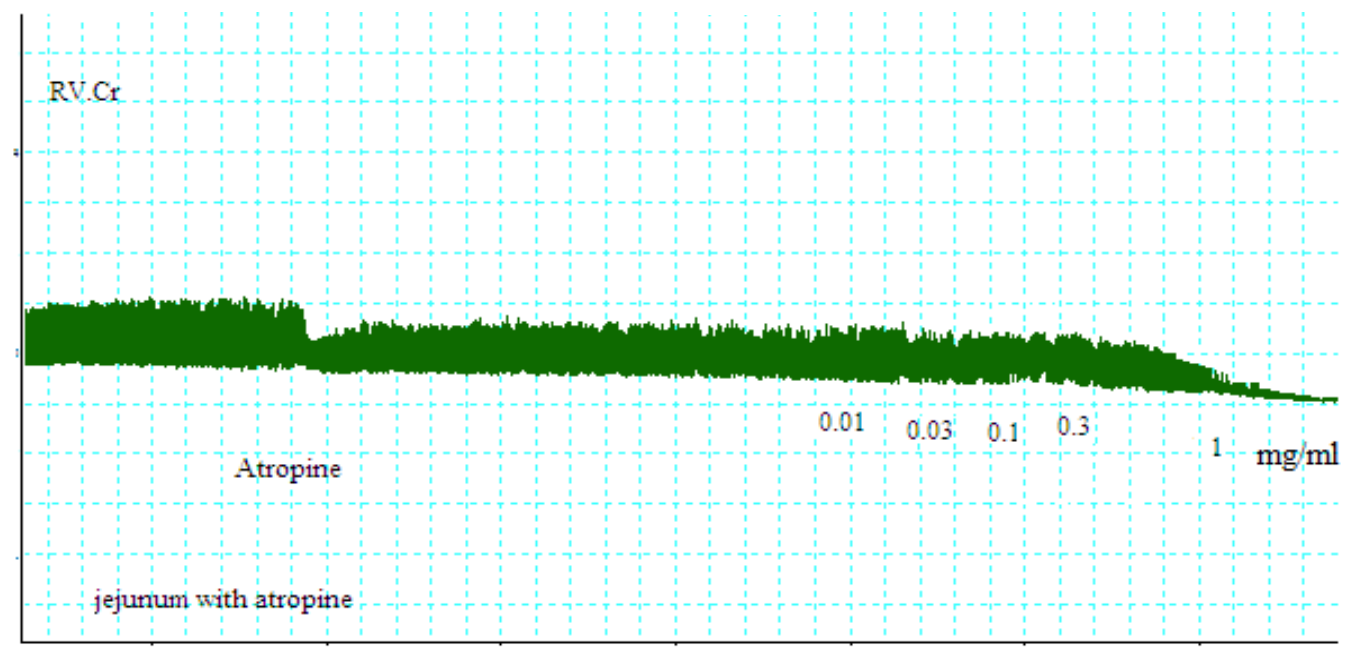

Figure 1. Tracing showing control (a) and the effect of crude methanolic extract of Rumex vesicarius leaf (Rv.Cr) on isolated rabbit jejunum preparations (b) and with atropine (c).

the following concentration $(\mathrm{mM}): \mathrm{KCl} 2.68, \mathrm{NaCl} 136.9, \mathrm{MgCl}_{2}$ 1.05, $\mathrm{NaHCO}_{3} 11.90, \mathrm{NaH}_{2} \mathrm{PO}_{4} 0.42, \mathrm{CaCl}_{2} 1.8$ and glucose 5.55 . The animals were then slaughtered and their abdomens were opened. Rabbit's jejunum portion(s), of about 1.5 to $2 \mathrm{~cm}$ length, was isolated and mounted in the tissue bath containing $10 \mathrm{ml}$ of Tyrode's solution maintained at $37^{\circ} \mathrm{C}$ and supplied with carbogen gas ( $5 \%$ carbon dioxide and oxygen mixture). These portion(s) were kept in Tyrode's solution previously aerated with the carbogen gas (Qayum, 2004). Earlier, the tissues were stabilized for normal activity for a period of about 25 to $40 \mathrm{~min}$. For possible pharmacological screening on the tissues through series of experiments, methanolic leaf extract of $R$. vesicarius was tried at doses of 0.01 to $05 \mathrm{mg} / \mathrm{ml}$. All the doses were applied in cumulative manner and the results were recorded (Farre et al., 1991). The spasmogenic and spasmolytic activity were recorded.

\section{Assay method}

\section{Isolated rabbit jejunum preparations}

The rabbit was starved over night and was sacrificed subsequent to a blow on the head. The abdomen was opened and jejunum was dissected out and cut to segments of about $2 \mathrm{~cm}$ in length following removal of adhering mesenteries. The segments were mounted between two stainless steel hooks in a $10 \mathrm{ml}$ tissue bath, containing normal Tyrodes solution ( $\mathrm{pH} \mathrm{7.4)}$, maintained at $37^{\circ} \mathrm{C}$ and aerated with carbogen $\left(5 \% \mathrm{CO}_{2}+95 \% \mathrm{O}_{2}\right)$. A preload of $1 \mathrm{~g}$ was applied and the tissue was allowed to equilibrate for a period of $30 \mathrm{~min}$ during which the tissue was washed with fresh fluid at an interval of every $10 \mathrm{~min}$ prior to exposure to any test material. The spontaneous contractions were recorded isotonically through a Power Lab Data Acquisition System (AD Instruments, Sydney, Australia) (Gilani et al., 2005).

\section{Determination of $\mathrm{Ca}^{++}$channel blocking activity}

The $\mathrm{Ca}^{++}$channel blocking activity was determined by application of the methanol extract on $\mathrm{K}^{+}-(80 \mathrm{mM})$ induced spastic contractions in isolated rabbit jejunum preparations (Fare et al., 1991). Isolated rabbit jejunum preparations exposed to $\mathrm{K}^{+}(80 \mathrm{mM})$ showed a sustained contraction. Extract was added in cumulative manner to demonstrate relaxation behaviour in jejunum preparation (VanRossum, 1963). Repeatedly, speculated that such relaxation was mediated through blockade of calcium channels (Bolton, 1979). 
Table 1. Phytochemical analysis of Rumex vesicarius (leaf) crude extracts (Rv.Cr).

\begin{tabular}{clll}
\hline $\mathbf{S} / \mathbf{N}$ & Test & Observation & Result \\
\hline 1 & Alkaloid & No precipitation & Negative \\
2 & Saponins & $1 \mathrm{~cm}$ froth & Positive \\
3 & Tannins & Light purple & Positive \\
4 & Anthraquinones & Pink & Positive \\
5 & Coumarins & Yellow fluorescence & Positive \\
6 & Phenols & Light purple & Positive \\
7 & Flavanoid & Light yellow colour & Positive \\
\hline
\end{tabular}

CCB effect of methanol extract was further confirmed by the previously reported method (Gilani et al., 2005). The isolated preparations were set to stabilized in normal Tyrode's solution, which was subsequently substituted with $\mathrm{K}^{+}$-normal, but $\mathrm{Ca}^{++}$-free Tyrode's solution. EDTA $(0.1 \mathrm{mM})$ was added to remove $\mathrm{Ca}^{++}$from the tissues. Solution was further replaced with $\mathrm{Ca}^{++}$-free and $\mathrm{K}^{+}$-rich Tyrode's solution. Incubated for $30 \mathrm{~min}, \mathrm{Ca}^{++}$was added to tissue bath to get control $\mathrm{Ca}^{++}$dose-response curves (CDRCs) in a cumulative manner. The gradual increase in contractile activity of the tissue depicted that the strength of contractions was dependent on the availability of extracellular $\mathrm{Ca}^{++}$for $\mathrm{K}^{+}$-induced influx of $\mathrm{Ca}^{++}$. After successive CDRCs, $\mathrm{Ca}^{++}$were found to be super imposable, and tissue was washed, and $60 \mathrm{~min}$ incubated for methanol extract. Then concentration response curves of $\mathrm{Ca}^{++}$were reconstructed and compared to the CDRCs. The concentration response curves for $\mathrm{Ca}^{++}$were developed in the presence of various concentrations of the methanol extract to assess a possible $\mathrm{Ca}^{++}$channel blocking effect (Bolton, 1979).

\section{Statistical analysis}

The results for spasmolytic and spasmogenic activities are expressed as the mean \pm standard error of mean (SEM). $E_{50}$ values with 95\% confidence interval were calculated using the computer software GraphPad Prism program version 6.0 for Windows (GraphPad, and San Diego, USA). Dose-response curves were analyzed by nonlinear regression sigmoidal response curve (variable slope).

\section{RESULTS}

Preliminary phytochemical screening detected the presence of tannins, phenols, saponins, anthraquinones and coumarins as constituents of the crude aqueousmethanolic extract of $R$. vesicarius (Rv.Cr), while it tested negative for the presence of alkaloid.

When tested on isolated rabbit jejunum, Rv.Cr showed spasmogenic as well as spasmolytic effect. The spasmogenic effect was observed at lower doses ( 0.03 to $0.3 \mathrm{mg} / \mathrm{ml})$, while at the next higher dose $(1 \mathrm{mg} / \mathrm{ml})$ relaxation of spontaneous and high $\mathrm{K}^{+}(80 \mathrm{mM})$ induced contractions $(0.03$ to $5 \mathrm{mg} / \mathrm{ml})$ with respective $E_{50}$ values of $1.886 \mathrm{mg} / \mathrm{ml}(1.576$ to 2.256$), 95 \% \mathrm{Cl}(\mathrm{n}=4)$ and $1.73 \mathrm{mg} / \mathrm{ml}(0.9740$ to $3.68, \mathrm{n}=04)$ and 2.088 (1.576 to $2.767), 95 \% \mathrm{Cl}(\mathrm{n}=4)$. Verapamil relaxed the spontaneous and high $\mathrm{K}^{+}(80 \mathrm{mM})$ induced contractions with respective $\mathrm{EC}_{50}$ vales of $0.13 \mathrm{uM}(0.104$ to $0.114, \mathrm{n}=4)$ and $0.013 \mathrm{uM}(0.0096$ to $0.0179, \mathrm{n}=4)$.

\section{DISCUSSION}

Phytochemical analysis of crude leaf extract of $R$. vesicarius (Rv.Cr) showed the presence of saponins, tannins, anthraquinones, coumarins, phenols, and flavonoid, while the alkaloid was absent as methanolic soluble constituents (Table 1 ).

As per Figure 1, there is moderate spasmogenic activity in the absence of atropine. That means muscarinic receptors were not blocked and the extract produced stimulation on the receptors, whereas, in pretreated atropine tissues (Figure 1; with atropine), the spasmogenic activity $(25 \pm 88 \%$ of control, $n=6, p \leq 0.05)$ was abolished. Its mechanism was attesting through muscarinic receptors because atropine is an antimuscarinic drug (Gilman et al., 1990). Thus, the left shift in $E C_{50}$ values in the activity $\left(E C_{50}\right.$ without atropine $=1.886 \mathrm{mg} / \mathrm{ml}(1.576$ to 2.256$), 95 \% \mathrm{Cl}, \mathrm{n}=4)$ and $E_{50}$ with atropine $=1.73 \mathrm{mg} / \mathrm{ml}(0.9740$ to $3.68, n=4)$ confirm the cholinomimetic activity (Figure 2). The most interesting phenomenon was observed with and without atropine complete relaxation of the tissue preparation observed at similar dose $(1 \mathrm{mg} / \mathrm{ml})$; although, the earlier doses in the absence of atropine spasmodic activity was observed, while all phenomenon replaced by spasmolytic activity in the presence of atropine. For further evaluation, tissues were depolarized with high potassium level (80 $\mathrm{mM}$ bath concentration) that produced a sustained contraction (Farre et al., 1991). Rv.Cr was then tried in cumulative manner to observe the spasmolytic effect on the tissues. As it has been regarded in previous multiple studies that contractions induced by potassium are mediated through calcium channels by influx of calcium from extra cellular fluid and a substance which will inhibit the contraction produced by $\mathrm{KCl}$ is considered to have calcium channel blocking activity (Bolton, 1979; Janbaz et al., 2012; Gilani et al., 2005; Brown and Taylor, 1996). According to Figure 3, the extract produced a spasmolytic effect on the $\mathrm{KCl}$ depolarized tissues, which attestifies further its calcium channel blocking activity depicted in 


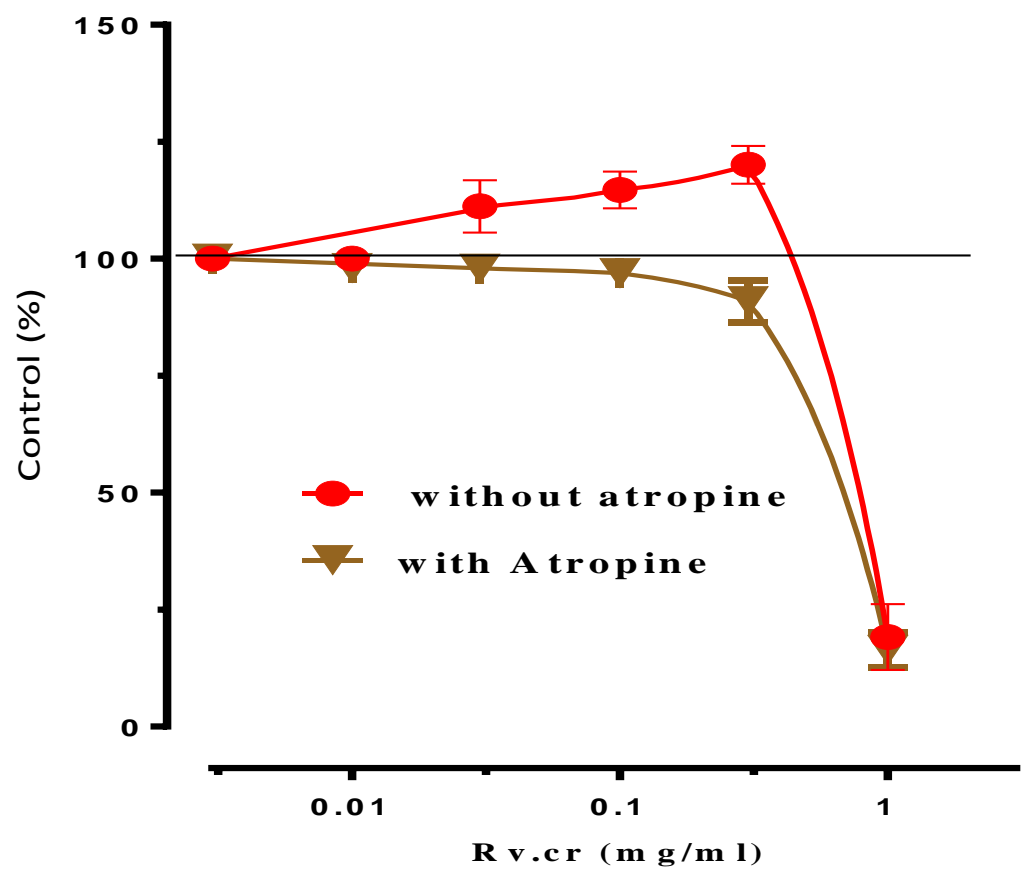

Figure 2. Effect of methanolic extract of Rv.Cr on atropinized and nonatropinized rabbit jejunum preparations. Values are mean \pm SEM, $n=5$.

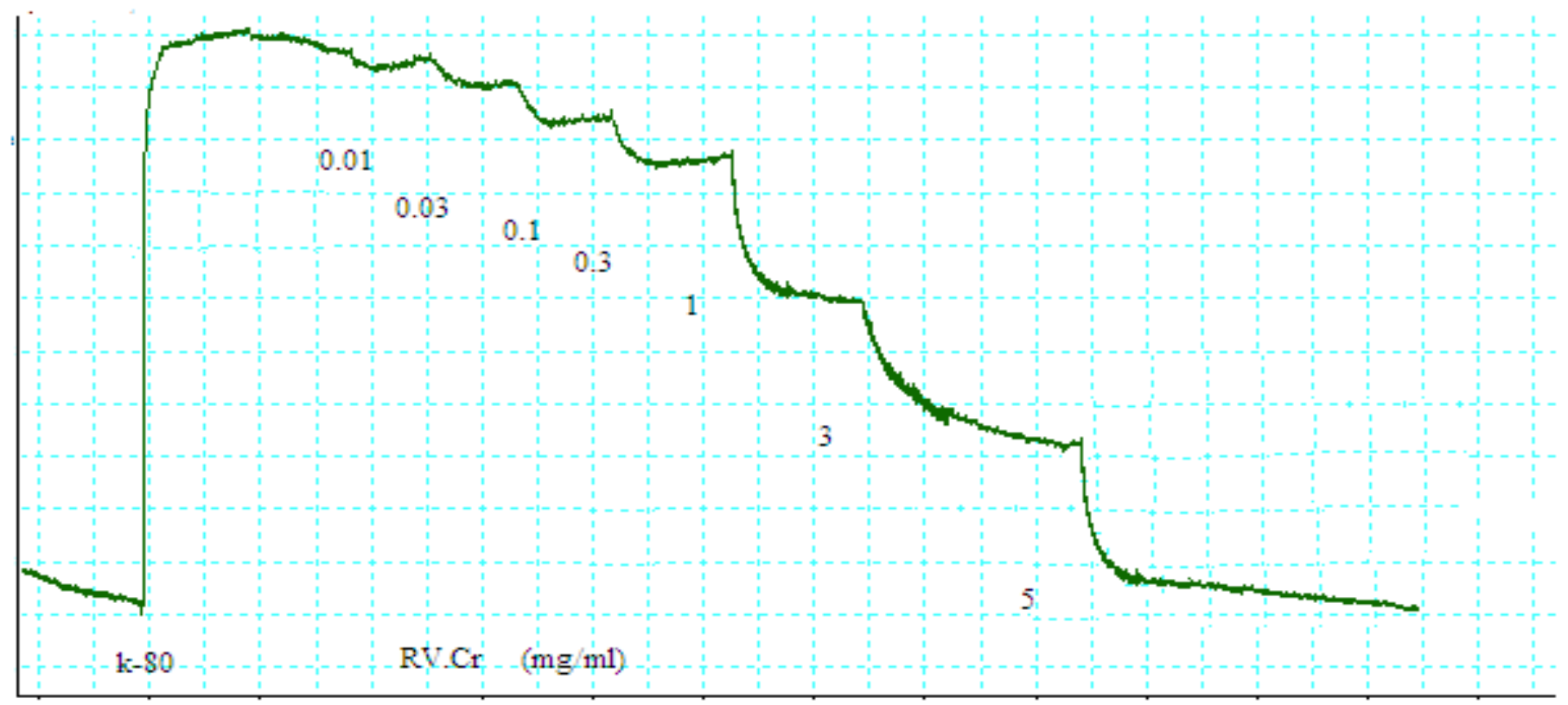

Figure 3. Trace showing the effect of crude methanolic extract of Rumex vesicarius leaf (Rv.Cr) on K-80 induced contractions on isolated rabbit jejunum preparations.

Figure 4. Furthermore, methanolic fraction of Rv.Cr was found capable of complete relaxation at $1 \mathrm{mg} / \mathrm{ml}$, most likely by calcium channel blockade (Figure 6). It was confirmed when it demonstrated the same pattern of activity as verapamil a standard calcium channel blocker (Figures 8 and 9). Furthermore, it shifted the calcium 


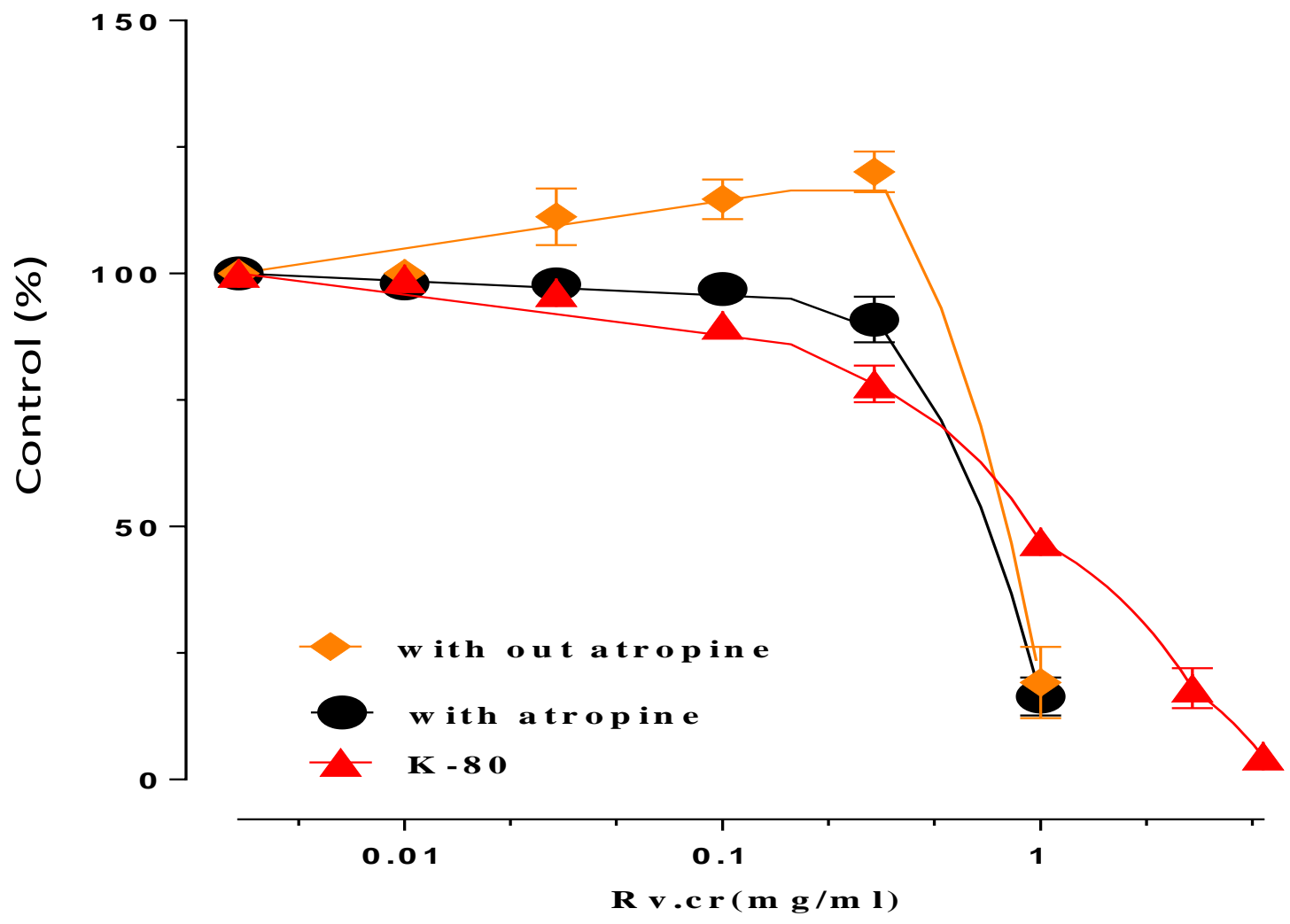

Figure 4. Effect of different concentrations of methanolic extract of Rv.Cr on atropinized and non-atropinized rabbit jejunum preparation as well as effect on K-80 induced contractions. (Value $\pm S E M, n=4)$.

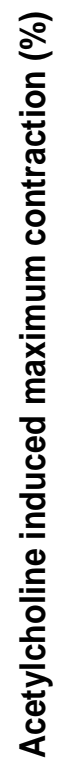

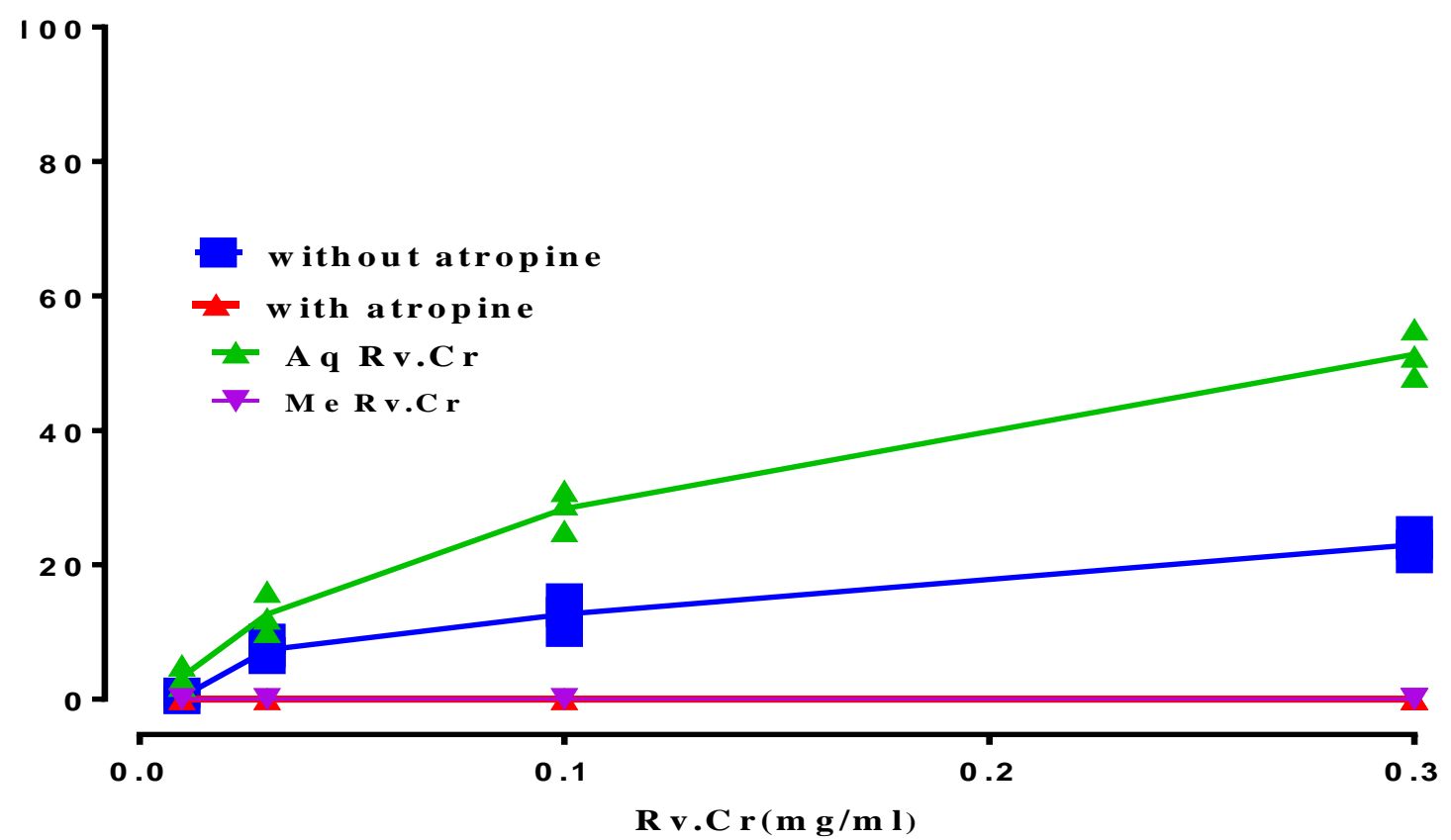

Figure 5. Concentration dependent spasmogenic effect of Rumex vesicarius leaf extract and fractions. The responses are given as percent of acetylcholine $(10 \mu \mathrm{M})$ induced maximum contraction. The values are shown as mean \pm SEM, $n=6$. 


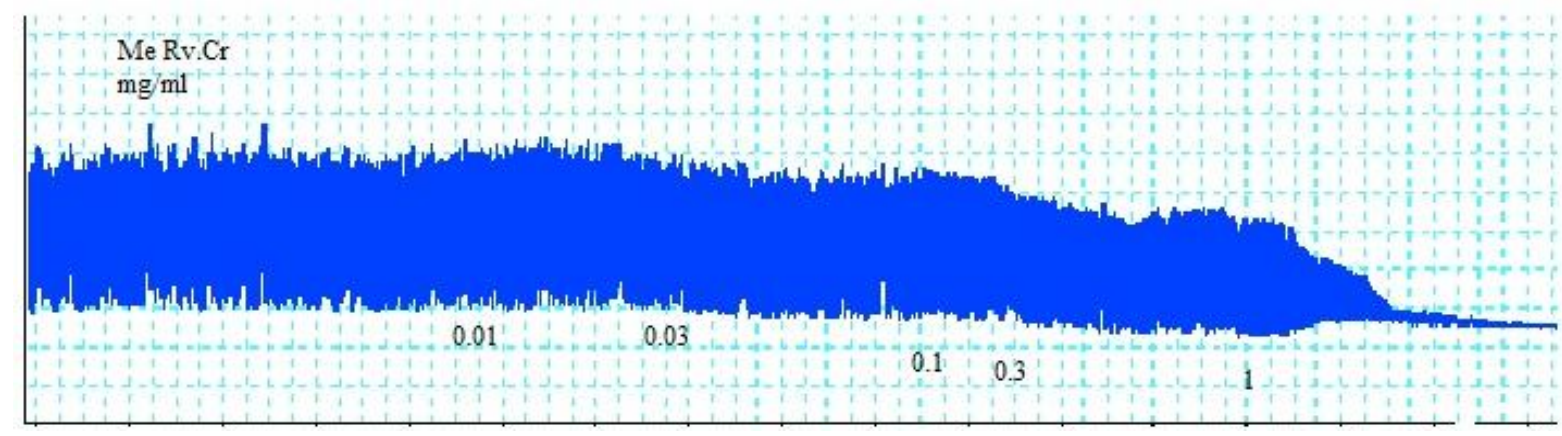

Figure 6. Trace showing the effect of crude methanolic fraction of Rumex vesicarius leaf ( Me Rv.Cr) on isolated rabbit jejunum preparations.

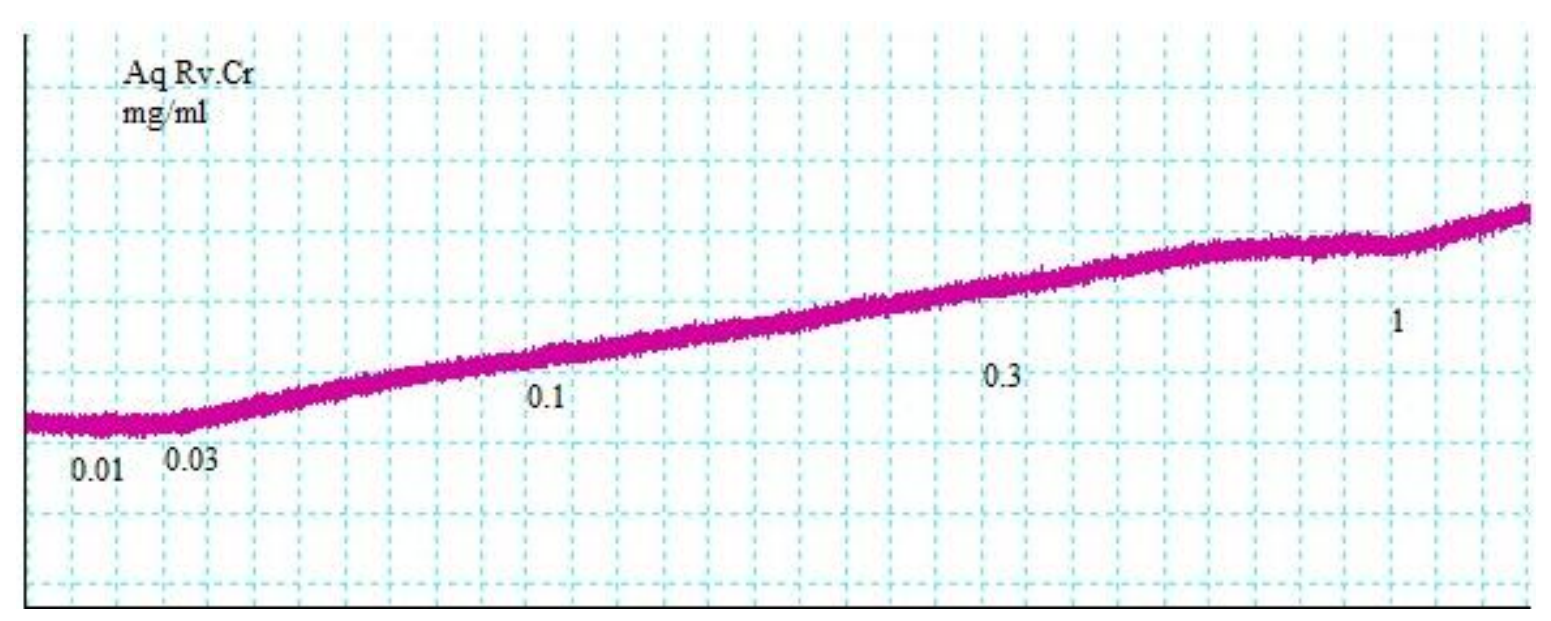

Figure 7. Tracing showing the effect of crude aqueous fraction of Rumex vesicarius leaf (Aq Rv.Cr) on isolated rabbit jejunum preparations.

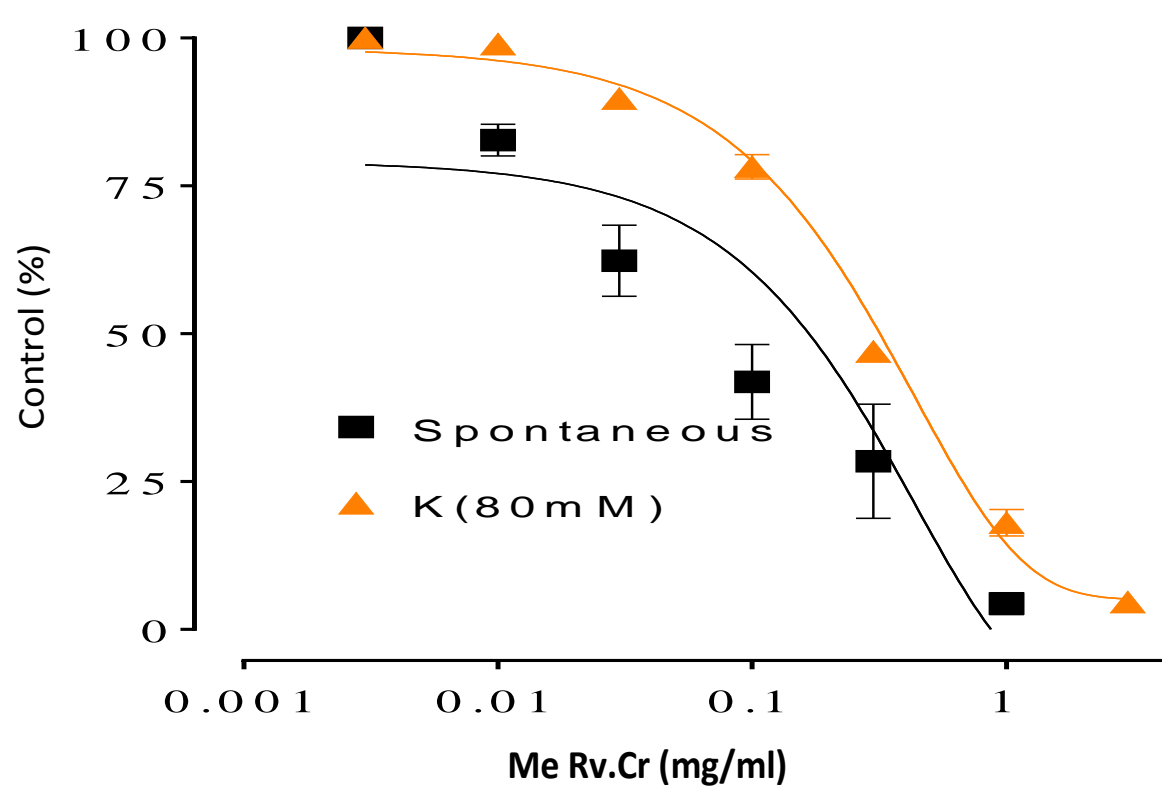

Figure 8. Concentration response curves showing the inhibitory effect of Me Rv.Cr on spontaneous and $\mathrm{K}_{+}(80 \mathrm{mM})$-induced contractions in isolated rabbit jejunum preparations. Values shown are mean \pm SEM of 5 observations. 


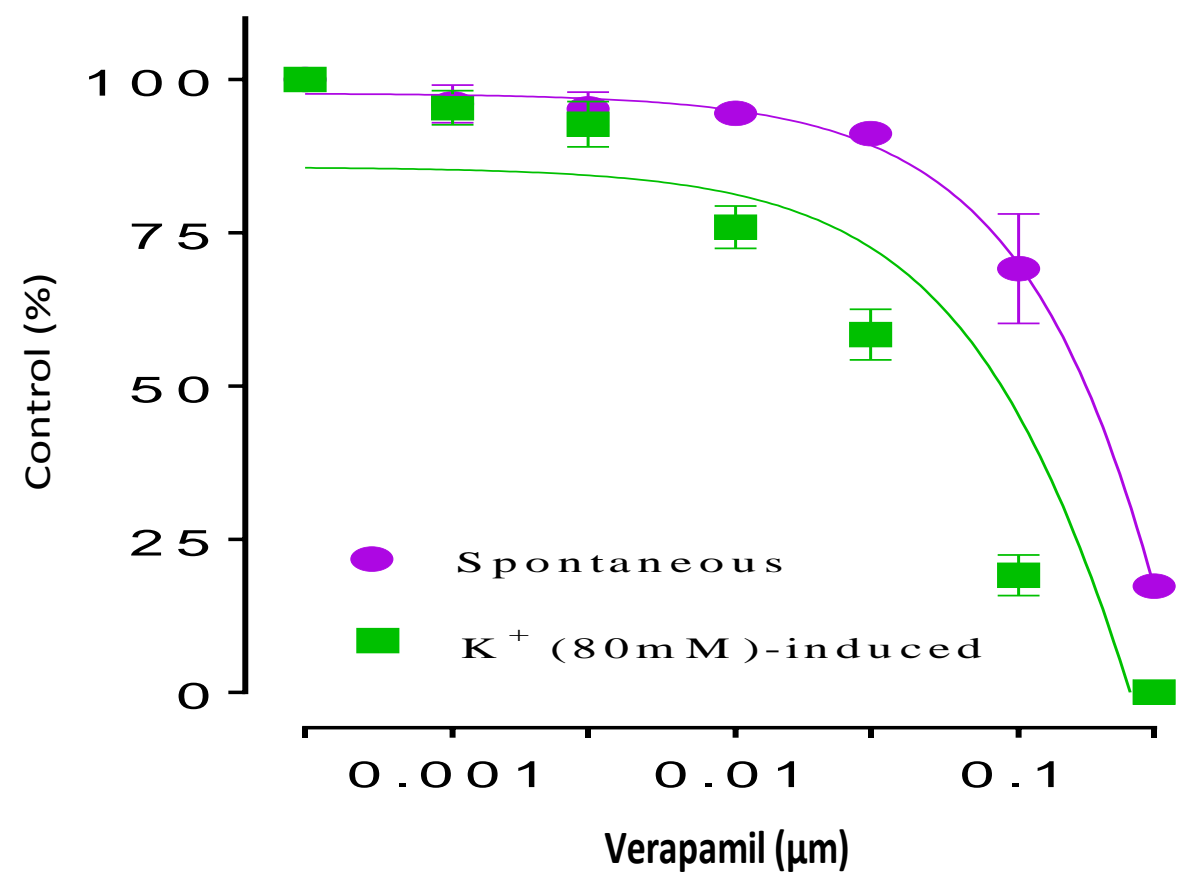

Figure 9. Concentration response curves showing the inhibitory effect of verapamil on spontaneous and $\mathrm{K}+(80 \mathrm{mM})$-induced contractions in isolated rabbit jejunum preparations. Values shown are mean \pm SEM of 5 observations.

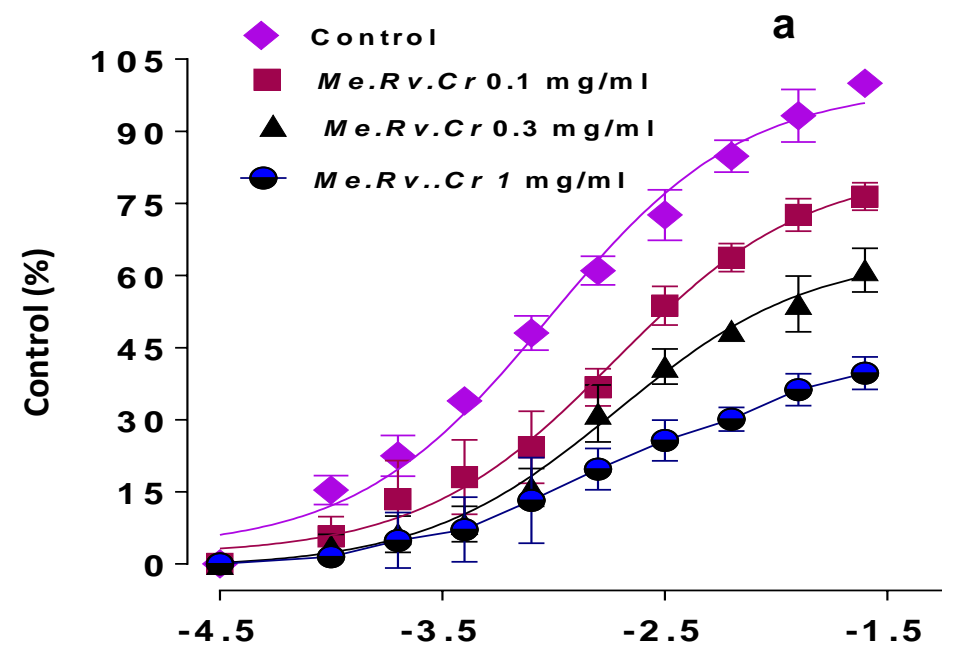

$\log \left[\mathrm{Ca}^{++}\right] \mathrm{M}$

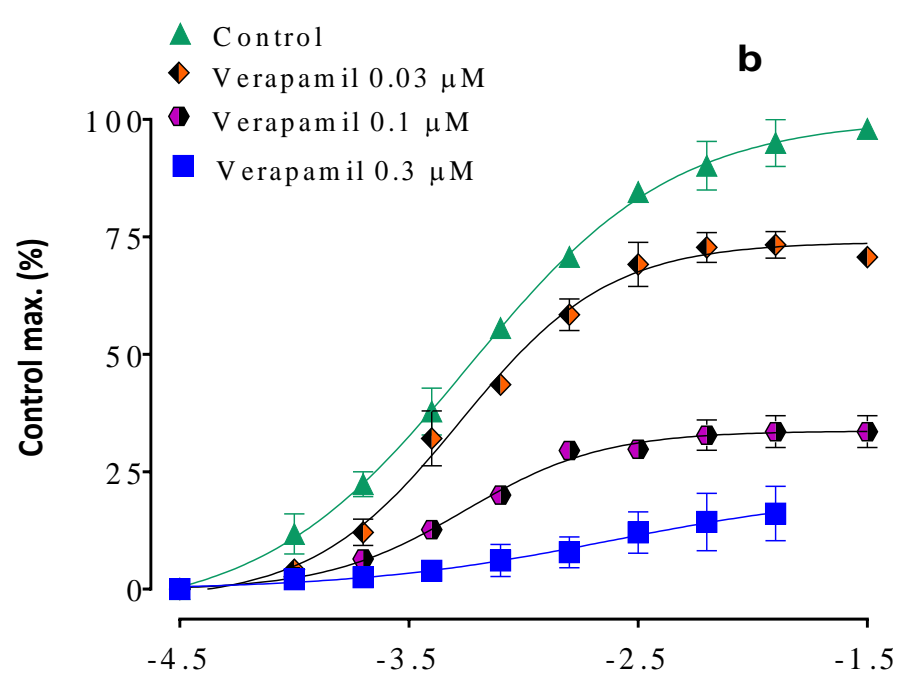

$\log \left[\mathrm{Ca}^{++}\right] \mathrm{M}$

Figure 10. Effect of (a) In. Cr and (b) verapamil (standard) on concentration-response curve of $\mathrm{Ca}^{2+}$ on isolated rabbit jejunum preparations (values are expressed as mean \pm SEM, $n=5$ ).

channel curves to the right same as verapamil (Figure $10 \mathrm{a}$ and $\mathrm{b})$. In contrast, its aqueous fraction showed more aggregated spasmogenic activity (51\%) than aqueousmethanolic extract $(25 \%)$ by cholinergic stimulations (Figure 5, 7). Aqueous methanolic extract and methanol and aqueous fractions all are acidic in nature (Table 2) which provides pharmacological reason for its use in alkalinity.

Rv.Cr was found safe in mice up to dose $2000 \mathrm{mg} / \mathrm{kg}$ indicating safe drug relatively to others in use. This data indicates that spasmogenic activity mediated gut stimulation through muscarinic receptors, while 
Table 2. Nature and percentage spasmogenic and spasmolytic activity of methanolic extract of extract Rumex vesicarius $L$. and its fractions.

\begin{tabular}{cccc}
\hline Extract & $\begin{array}{c}\text { Spasmogenic } \\
\text { activity (\%) }\end{array}$ & $\begin{array}{c}\text { Spasmolytic } \\
\text { activity (\%) }\end{array}$ & Nature \\
\hline Rv.Cr & 25 & 99 & Acidic \\
Aq Rv.Cr & 51 & 8 & Acidic \\
Me Rv.Cr & 0 & 99 & Acidic \\
\hline
\end{tabular}

spasmolytic activity was through CCB.

\section{ACKNOWLEDGEMENT}

The authors are thankful to Dr. Khalid Hussain Janbaz (Dean) for his guidance throughout the experiment

\section{Conflict of Interests}

The author(s) have not declared any conflict of interests.

\section{REFERENCES}

Ahirrao YA., Patil DA (2012). Ethnomedicinal claims against stomach complaints in Buldhana District (Maharashtra, India) Life sci. Leafl. $1: 16-25$

Allen SJ, Okoko B, Martinez E, Gregorio G, Dans LF (2004). Probiotics for treating infectious diarrhea. Cochrane Database Syst. Rev. 2: 3048

Amira M, Abu-Taleb, Kadriya El- Deeb, Fatimah O. Al-Otibi (2011). Assessment of antifungal activity of Rumex vesicarius $L$. and Ziziphus spina-christi (L.) Willd. extracts against two phytopathogenic fungi. Afr. J. Microbiol. Res. 5(9):1001-1011.

Aggarwal BB, Ichikawa H, Garodia P, Weerasinghe P, Sethi G, Bhatt ID, Pandey MK, Shishodia S, Nair MG (2006). From traditional Ayurvedic medicine to modern medicine: identification of therapeutic targets for suppression of inflammation and cancer Expert Opin. Ther. Targets 10(1):88-118

Bolton TB (1979). Mechanisms of action of transmitters and other substances on smooth muscle. Physiol. Rev. 59:606-718.

Brown JH, Taylor $P$ (1996). Muscarinic receptor agonists and antagonists. In: Goodman LS, Gilman A, Hardman JG, Gilman AG, Limbird LE (eds.), Goodman \& Gilman's The Pharmacological Basis of Therapeutics. McGraw-Hill, New York. pp. 141-160.

Dymoke W (1972). A History of the Principal Drugs of the Vegetable Origin, 2nd ed. Pharmacographia Indica. Hamdard publications Karachi, Karachi. Pakistan. P 2114.

Farre AJ, Colombo M, Fort M, Gutierrez B (1991). "Differential effects of various Ca2+ antagonists," Gen. Pharmacol. 22(1):177-181.

Gilani AH, Khalid A, Zaheer-ul-Haq M, Choudhary I, Atta-ur-Rahman (2005). Presence of antispasmodic, antidiarrheal, antisecretory, calcium antagonist and acetylcholinesterase inhibitory steroidal alkaloids in Sarcococca saligna. Planta Med. 71:120-125.

Harborne JB (1973). Methods of plant analysis.In, Phytochemical Methods.Champan and Hall, London. pp. 1-7.
Hariprasad PS (2011). Phytochemical screening and pharmacognistic evaluation of Rumex vesicarius L. Int. J. Pharmtech Res. 3(2):10781082.

Janbaz KH, Latif MF, Saqib F, Imran I, Zia-Ul-Haq M, Vincenzo De Feo (2013). Pharmacological Effects of Lactuca serriola L. in Experimental Model of Gastrointestinal, Respiratory, and Vascular Ailments. Compliment. Altern. Med. 46:335-349.

Khan IA, Aziz A, Munawar SH, Munzoor Z (2013). Antiemetic Activity of Methanolic Leaf Extract of Rumex vesicarius Linn. Int. J. Pharm. Res. Allied Sci. 2(4):33-37

Kirtikar KR, Basu BD (1987). Indian Medicinal plants. Vol III, 2nd ed. Dehradun, India: popular publishers. pp. 1961-1963, 1023-1028.

Madhavashetty K, Shivaji K, Tulasirao K (2008). Flowering plants of Chittor District, Andhra Pradesh, India, 2nd edition. Students offset printer. P 298.

Rao R (2003). Bioactive phytochemicals in Indian foods and their potential in health promotion and disease prevention. Asia Pac. J. Clin. Nutr. 12(1):9-22

Nardkarnis KM (2002). Indian materia medica, Vol 1. Popular prakashan Pvt. Ltd. pp. 1080-1081.

Pullaiah T, Ali MD (1997). Flora of Andhra Pradesh (India), Vol 2. Scientific Publishers. P 817.

Qayum A (2004). Isolated preparations. Guidelines and instructions. In: Fundamentals of Experimental Pharmacology, 1st ed. New Awan Printers, Peshawar. pp. 401-416.

Quyang H, Chen JH (2004). Review article: therapeutic roles of acupuncture in functional gastrointestinaldisorders. Aliment. Pharmacol. Ther. 20(8):831-841.

Rao KN, Sunitha Ch, David B, Sandhya S, Shwetha D, Murali K (2011). Diuretic activity on different extracts and formulation on aerial parts of Rumex vesicarius Linn. J. Chem. Pharm. Res. 3(6):400-408.

Rao KN, Sunitha Ch, Sandhya S, Rajeshwar T (2012). Anthelminthic activity of different extracts on aerial parts of Rumex vesicarius linn. Int. J. Pharm. Sci. Rev. Res. 12:64-66.

Thapar N, Sanderson IR (2004). Diarrhea in children: an interface between developing and developed countries. Lancet. 363:641-653.

Tona L, Kambu K, Ngimbi N, Cimanga K, Vlietink AJ (1998). Antiamoebic and Phytochemical Screening of Some Congolese Medicinal Plants. Planta Med. 61(1):57-65

Van-Rossum JM (1963). Cumulative dose-response curves. II. Technique for the making of dose-response curves in isolated organs and the evaluation of drug parameters," Arch. Int. Pharmacodyn. Ther. 43:299-330 